\title{
Protective Role of Superoxide Dismutase against
}

\section{Diabetogenic Drugs}

\author{
Samuel E. Gandy, Maria G. Buse, and Rosalie K. Crouch, Departments of \\ Biochemistry, Medicine, and Ophthalmology, Medical University of South \\ Carolina, Charleston, South Carolina 29425
}

A B S T R A C T Copper-zinc superoxide dismutase (SOD) is present in relatively high concentrations in the $\beta$-cells of human islets. The activity of the extracted enzyme is partially inhibited upon incubation with the diabetogenic drugs alloxan, streptozotocin, or Vacor. The role of this enzyme in protecting $\beta$-cells against chemically induced diabetes was further investigated.

Incubation of intact canine islets with alloxan $(0.2$ $\mathrm{mg} / \mathrm{ml}$ ) and $4 \mathrm{mM}$ glucose decreased the insulin secretory response by $87 \%$ during subsequent exposure to $28 \mathrm{mM}$ glucose. Concomitantly the SOD-specific activity (units of enzyme activity per milligram immunoreactive SOD) decreased $50 \%$ in alloxan-exposed islets. When islets were protected from alloxan toxicity by including $28 \mathrm{mM}$ glucose with alloxan, the insulin secretory response and SOD specific activity remained identical to controls. Thus, SOD specific activity correlates with maintenance of $\beta$-cell function.

To test the effectiveness of SOD against streptozotocin in vitro, canine islets were incubated $10 \mathrm{~min}$ with or without streptozotocin $(0.1 \mathrm{mg} / \mathrm{ml})$ with $4 \mathrm{mM}$ glucose; their functional integrity was tested subsequently as the insulin secretory response to $28 \mathrm{mM}$ glucose. Exposure to streptozotocin alone decreased the response by $70 \%$; inclusion of SOD $(1.5 \mathrm{mg} / \mathrm{ml})$ before and during exposure to streptozotocin completely prevented this effect. Cyanide-inactivated SOD was not effective.

The potential of SOD to prevent streptozotocin-induced diabetes was tested in rats in vivo. SOD injected $10 \mathrm{~s}$ or $50 \mathrm{~min}$ before streptozotocin prevented or significantly attenuated diabetes. Injection of SOD and streptozotocin simultaneously was much less effective, and cyanide-inactivated SOD was ineffective. No protection was afforded by injection of SOD 12 or $24 \mathrm{~h}$ before streptozotocin.

Received for publication 9 March 1982 and in revised form 26 May 1982.
Our results support hypotheses that $(a)$ oxygen radicals mediate the $\beta$-cell toxicity of both alloxan and streptozotocin, and (b) $\beta$-cells may be particularly vulnerable to oxygen radical damage.

\section{INTRODUCTION}

Streptozotocin and alloxan are widely used in studies of experimental diabetes because these agents destroy the pancreatic $\beta$-cells with relative selectivity. Recent evidence indicates that the generation of superoxide radicals may mediate the cytotoxic effects of these drugs on $\beta$-cells although this has only been clearly demonstrated for alloxan (1).

Superoxide dismutase (superoxide oxidoreductase, E.C. 1.15.1.1., SOD) ${ }^{1}$ is a widely distributed enzyme that scavenges superoxide radicals. In eukaryotic cells CuZnSOD is primarily located in the cytosol and MnSOD in the mitochondria (2). We have previously reported that the islets of Langerhans are relatively rich in CuZnSOD (3) and observed selective localization of the enzyme in the human $\beta$-cell (4).

The diabetogenic drugs alloxan, streptozotocin, and Vacor cause partial inhibition of the biological activity of CuZnSOD, but not MnSOD, in vitro and in vivo. The in vitro inhibition was shown with the purified erythrocyte enzyme as well as with intact erythrocytes or the enzyme extracted from islets. The in vivo inhibition was relatively tissue specific and was observed in erythrocytes and retinae of the rat after injection of streptozotocin or alloxan but not in a number of other tissues studied (5). No information is available concerning the in vivo effects of diabetogenic agents on the SOD activity of the $\beta$-cell.

\footnotetext{
${ }^{1}$ Abbreviations used in this paper: ANOVA, analysis of variance; CNSOD, cyanide-inactivated superoxide dismutase; GTT, glucose tolerance test; PBS, phosphate-buffered saline; PEG, polyethylene glycol; SOD, superoxide dismutase.
} 
The above experiments suggested that the diabetogenic drugs may exert their cytotoxic effects in part by inhibiting SOD in $\beta$-cells. Administration of a glucose load before alloxan is known to prevent its diabetogenic effect (6). However, injection of glucose before alloxan prevented diabetes but not the alloxaninduced inhibition of erythrocyte SOD (5). Evidently, if SOD inhibition plays a role in the diabetogenic effect of alloxan, glucose would have to protect $\beta$-cell SOD from alloxan.

Several studies indicate that incubation of isolated pancreatic islets with chemical scavengers of oxygen radicals, including SOD, protects the islets against the toxic effects of alloxan (7). No such information is available concerning the effects of streptozotocin in vitro. Robbins et al. (8) reported that pretreatment of rats with intravenous SOD protected against streptozotocin-induced diabetes; however, a recent report by Gold et al. (9) questioned these observations. The latter authors concluded that SOD therapy was ineffective in protecting mice against streptozotocin diabetes or rat islets against streptozotocin toxicity in vitro.

The fact that $\beta$-cells contain much more SOD than $\alpha$-cells or cells of the exocrine pancreas (4) suggested that this enzyme may play an important role in $\beta$-cell homeostasis. Thus, further studies concerning islet SOD and its interaction with the diabetogenic drugs seemed warranted. In this report the following questions are addressed. Does alloxan inhibit SOD in the intact islet? If so, is this inhibition prevented by high concentrations of ambient glucose? Does SOD protect $\beta$-cells against the toxic effects of streptozotocin in vitro and/or in vivo? If SOD administration protects $\beta$-cells, does it exert its effect by interacting with the diabetogenic agents before they reach the cell, by protecting cell components from oxygen radicals generated outside the cell, or by entering the $\beta$-cell?

\section{METHODS}

\section{Reagents}

Purified canine and bovine erythrocyte SOD, alloxan monohydrate, collagenase (type V), cyanuric acid, and amylase assay kits were obtained from Sigma Chemical Co. (St. Louis, MO). Streptozotocin was kindly supplied by Dr. William Dulin, Upjohn Co. (Kalamazoo, MI). Tissue culture medium 199, goat antiserum to rabbit globulin, and fetal bovine serum were obtained from Grand Island Biological Company (Grand Island, NY). Pyrogallol and sodium diethylenepentaminetetraacetic acid were obtained from Fisher Scientific Co., Pittsburgh, PA. Methoxypolyethylene glycol (Carbowax 2000) was the gift of Union Carbide Corp., S. Plainfield, NJ. Carrier-free $\left[{ }^{125} I\right]$ sodium iodide was obtained from Amersham Corp. (Arlington Heights, IL) and lactoperoxidase-glucose oxidase enzymobeads from Bio-Rad Laboratories, Richmond, CA. Aprotonin (Trasylol) was purchased from Mobay Chemicals (New York).

\section{Superoxide dismutase derivatizations}

Polyethylene glycol-derivatized SOD (PEG-SOD) was prepared by the procedure of Abuchowski et al. (10) by cyanuric acid coupling of SOD to methoxypolyethylene glycol (Carbowax 2000). Purity of the product was determined by gel electrophoresis on $7.5 \%$ polyacrylamide $\left(R_{f}=0.10\right.$ $0.18)$. PEG-SOD enzyme activity was $30-40 \%$ of that of the native SOD. Cyanide-inactivated SOD (CNSOD) was prepared by reacting SOD with KCN (10 M excess) for $20 \mathrm{~min}$. Absence of SOD activity was confirmed by enzyme assay. Free cyanide was removed by dialysis against distilled water (14 changes). SOD derivatives were lyophilized and stored at $-70^{\circ} \mathrm{C}$ until use.

\section{Isolation and maintenance of pancreatic islets of Langerhans}

Islets were prepared from freshly killed mongrel dogs as previously described (11-13). Islet preparations were allowed to incubate at $37^{\circ} \mathrm{C}$ in tissue culture medium 199 with $15 \%$ fetal bovine serum under $95 \%$ air $/ 5 \% \mathrm{CO}_{2}$ for $16-18$ $h$ with two to three medium changes. This method results in relative enrichment of islets because much of the exocrine tissue undergoes autolysis and islet harvesting is facilitated (14). The purity of a representative islet preparation was evaluated by the insulin/amylase ratio as described by Matas et al. after overnight culture in Medium 199 (glucose 5.5 $\mathrm{mM}$ ) and was found to be $67 \mu \mathrm{g}$ insulin per milligram amylase (11). Viability of islets was evaluated by their response to increased glucose concentration with release of insulin (Tables I and II).

\section{SOD assays}

Activity assay. Enzymatic activity was determined by spectrophotometric assay based upon the ability of SOD to inhibit the autooxidation of pyrogallol in basic solution (15). Intraassay variability was $15 \pm 3 \%(n=30)$ while interassay variability was $7.8 \pm 2 \%(n=3)$. One unit of activity is the amount of enzyme that inhibits pyrogallol autoxidation by $50 \%$.

For presentation of data, enzyme activity measurements were converted to the more widely used "xanthine oxidase" units ( 1 pyrogallol $U=0.333$ xanthine oxidase $U=100 \mathrm{ng}$ purified bovine erythrocyte SOD) (15).

Radioimmunoassay. Immunoreactive SOD was determined by competitive binding radioimmunoassay using an antibody specific for canine CuZnSOD. Rabbit antiserum to canine erythrocyte SOD was characterized on double diffusion Ouchterlony plates as described (3). Purity of antigen (98\%) was established by a single protein band on polyacrylamide gels $(7.5 \%)$ and by the specific activity (enzyme activity units per milligram) of the protein. Iodination was modified after the method of Marchalonis (16), using lactoperoxidase coupled to insoluble beads, which yielded ${ }^{125} \mathrm{I}$ SOD of sp act $67-160 \mu \mathrm{Ci} / \mathrm{mg}$. Free iodide was separated from ${ }^{125}$ I-SOD by gel filtration over Sephadex G-25. The product was identified as ${ }^{125}$ I-SOD by isoelectric focusing on polyacrylamide gels $(7.5 \%, \mathrm{pH} \mathrm{4-6)}$ and staining for SOD enzymatic activity (17). Serial $5 \mathrm{~mm}$ gel slices were counted; radioactivity was associated exclusively with the SOD band. ${ }^{125}$ I-SOD was $95-100 \%$ precipitable with either trichloroacetic acid $(10 \mathrm{~g} / 100 \mathrm{ml})$ or anticanine SOD antiserum/goat antirabbit $\gamma$-globulin. 


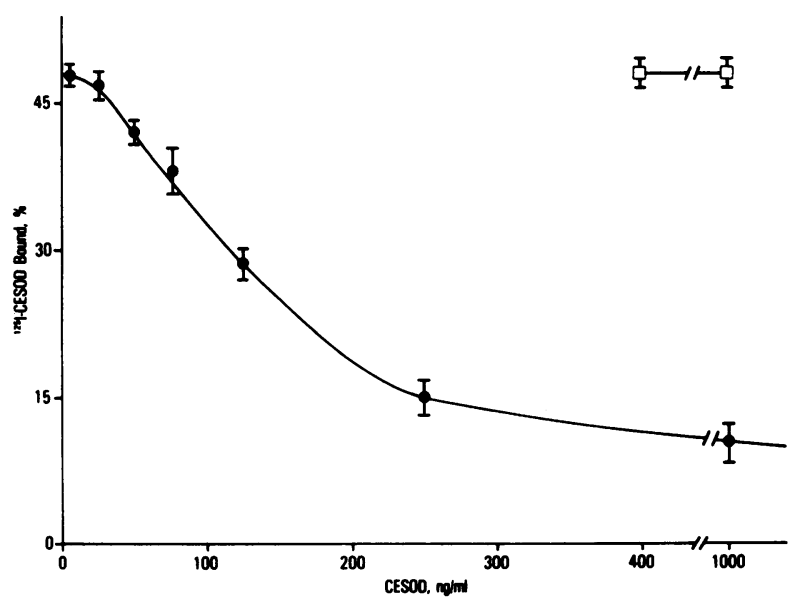

Figure 1 Standard radioimmunoassay for canine erythrocyte superoxide dismutase (CESOD). Canine SOD concentration, $\mathrm{ng} / \mathrm{ml}(--O)$; rabbit SOD concentration, $\mathrm{ng} / \mathrm{ml}$ $(\square-\square)$. Measurements are expressed as mean $\pm \mathrm{SEM}, n$ $=6$. Total $\mathrm{cpm}$ per tube $=10,000$.

In the standard assay, $33 \mathrm{ng}{ }^{125} \mathrm{I}-\mathrm{SOD}$ and $100 \mu \mathrm{l}$ rabbit anticanine SOD $(1: 2,000)$ were incubated with $50 \mu$ l unlabeled SOD $(1 \mathrm{ng} / \mathrm{ml}$ to $1 \mu \mathrm{g} / \mathrm{ml})$ in a total volume of 500 $\mu l$ in $0.3 \mathrm{M}$ borate buffer containing $5 \mathrm{~g} / 100 \mathrm{ml}$ bovine serum albumin, $\mathrm{pH} 8.6$, at $4^{\circ} \mathrm{C}$ for $24 \mathrm{~h}$. Immune complexes were precipitated by incubating at $4^{\circ} \mathrm{C}$ for $24 \mathrm{~h}$ with $100 \mu$ l goat antirabbit globulin (diluted 1:6 in 5\% bovine serum albumin/ borate). Samples were centrifuged $(4,500 \mathrm{~g}, 30 \mathrm{~min}$.), and the precipitate was counted in a Beckman $4000 \gamma$-counter (Beckman Instruments, Inc., Fullerton, CA). Precipitates of blanks prepared without SOD antiserum contained 15-22\% of total precipitable activity in the presence of antibody and were subtracted from all assay samples. All measurements were made in triplicate at two dilutions.

A representative curve is shown in Fig. 1; the assay is linear between $5 \mathrm{ng} / \mathrm{ml}$ and $100 \mathrm{ng} / \mathrm{ml}$. Specificity for canine SOD was demonstrated by absence of crossreactivity with rabbit CuZnSOD. Serial dilutions were assayed for SOD enzymatic activity and immunoreactivity; specific activity (units enzyme activity per milhigram immunoreactive SOD) was $97 \%$ of the expected specific activity of the purified erythrocyte enzyme.

The effect of alloxan on the radioimmunoassay was tested both by the addition of the drug ( $1 \mathrm{fM}-1 \mathrm{M})$ to the standard radioimmunoassay system and by incubating SOD $(0.49 \mu \mathrm{M})$ with the drug $(40 \mathrm{mM})$ at $25^{\circ} \mathrm{C}$ for $15 \mathrm{~min}$ before radioimmunoassay and bioassay.

\section{In vitro studies}

Canine islets were rinsed thoroughly with phosphate-buffered saline (PBS) and allowed to sediment. All experiments were carried out at $37^{\circ} \mathrm{C}$ under incubator conditions, using $\sim 100$ islets/dish in $3 \mathrm{ml}$ PBS containing $2 \mathrm{mg} / \mathrm{ml} \mathrm{BSA}, 100$ $\mathrm{U} / \mathrm{ml}$ Trasylol, and other additions as indicated.

Alloxan effect on specific activity of canine islet SOD; protection by $D$-glucose. Islets were preincubated for 10 min with either low $(4 \mathrm{mM})$ or high $(28 \mathrm{mM})$ D-glucose. Alloxan $(0.2 \mathrm{mg} / \mathrm{ml})$ was added for $5 \mathrm{~min}$ to some samples.
After washing with 50 vol PBS $(\times 3)$ the islets were exposed either to PBS-high glucose to stimulate insulin secretion or to PBS-low glucose to allow identification of samples releasing insulin secondary to alloxan damage. After $1 \mathrm{~h}$ the supernatant was decanted, and insulin in the medium was measured by radioimmunoassay with a procedure (18) modified from Morgan and Lazarow (19). The islets were sonicated in $1 \mathrm{ml}$ water at $50 \mathrm{~W}$ for $1 \mathrm{~min}$ at $4^{\circ} \mathrm{C}$. Insoluble cell components were removed by centrifugation at $500 \mathrm{~g}$ for 15 min. The supernatant was frozen at $-70^{\circ} \mathrm{C}$ for subsequent assay of SOD enzymatic activity and immunoreactivity.

$S O D$ protection against streptozotocin. Islets were preincubated for $10 \mathrm{~min}$ with or without SOD $(1.5 \mathrm{mg} / \mathrm{ml})$ or CNSOD $(1.5 \mathrm{mg} / \mathrm{ml})$, then streptozotocin $(0.1 \mathrm{mg} / \mathrm{ml})$ was added to some dishes for 10 additional min. Islets were washed in 50 vol PBS and resuspended in PBS-low glucose or PBS-high glucose. After $1 \mathrm{~h}$, islets were removed and insulin in the medium was assayed.

\section{In vivo experiments}

Rats. Male Wistar rats (Charles River Breeding Laboratories, Inc., Wilmington, MA), 175-225 g, were fasted for $18 \mathrm{~h}$ and anesthetized with methoxyflurane before injection via the tail vein. Bovine erythrocyte SOD was administered in $100 \mathrm{mM}$ sodium acetate/acetic acid buffer, pH 5.2, 105 $\mathrm{U}(=35 \mu \mathrm{g}) / \mathrm{g}$ body $\mathrm{wt}, 40 \mathrm{mg} / \mathrm{ml}$. In one series one half this dose was used. PEG-SOD was assayed enzymatically and the quantity of PEG-SOD increased to deliver identical activity per gram body weight to that delivered with the native enzyme. Gram-equivalent doses of CNSOD ( $35 \mu \mathrm{g} / \mathrm{g}$ body wt) were substituted for native SOD. Streptozotocin $(50 \mathrm{mg} / \mathrm{kg}$ body wt, $42 \mathrm{mg} / \mathrm{ml}$ ) was solubilized immediately before injection in $100 \mathrm{mM}$ sodium acetate/acetic acid buffer, $\mathrm{pH}$ 5.2. In one series, streptozotocin $(42 \mathrm{mg} / \mathrm{ml})$ was incubated for $15 \mathrm{~min}$ at $37^{\circ} \mathrm{C}$ in $100 \mathrm{mM}$ sodium acetate/acetic acid buffer, pH 5.2 , with and without SOD $(40 \mathrm{mg} / \mathrm{ml})$.

Experimental animals received native or derivatized SOD at various time intervals before streptozotocin $(10 \mathrm{~s}-24 \mathrm{~h})$ or streptozotocin incubated with SOD. Controls were injected with one of the following: vehicle, SOD, streptozotocin, or streptozotocin incubated in vehicle.

$5 \mathrm{~d}$ after injection, food was withheld from 4 p.m. until 10 a.m. the next morning, when glucose tolerance tests (GTT) were performed. Freely flowing blood was collected from cut tails. After obtaining a base-line sample ( $0 \mathrm{~min}$ ), glucose $\left(1 \mathrm{~g} / \mathrm{kg}\right.$ body wt, $\left.0.25 \mathrm{~g} / \mathrm{ml} \mathrm{H}_{2} \mathrm{O}\right)$ was injected i.p., and blood samples were taken at 15,30 , and $60 \mathrm{~min}$. Animals were maintained under light methoxyflurane anesthesia for the duration of GTT. Plasma glucose was analyzed immediately by the Beckman glucose oxidase/oxygen system (Beckman Instruments, Inc., Fullerton, CA). In some experiments random nonfasting plasma glucose concentration was determined on blood samples obtained by cardiac puncture. All animals were monitored for glycosuria with TesTape (Eli Lilly \& Co., Indianapolis, IN). Rats injected with streptozotocin alone had $3-4^{+}$glycosuria and random, nonfasting plasma glucose levels exceeding $300 \mathrm{mg} / 100 \mathrm{ml}$ (mean $410 \pm 45, n=5$ ).

Nonfasting plasma glucose levels were not measured before GTT in the experiments shown in Figs. 2a and b. After an 18-h fast, the mean plasma glucose of all rats injected with streptozotocin alone was $94 \pm 7.2 \mathrm{mg} / 100 \mathrm{ml}(n=24)$ vs. $62 \pm 7(n=9)$ in controls $P<0.02)$. In view of $3-4^{+}$glycosuria and previous experience with rats injected under identical conditions with $50 \mathrm{mg} / \mathrm{kg}$ streptozotocin i.v., gly- 

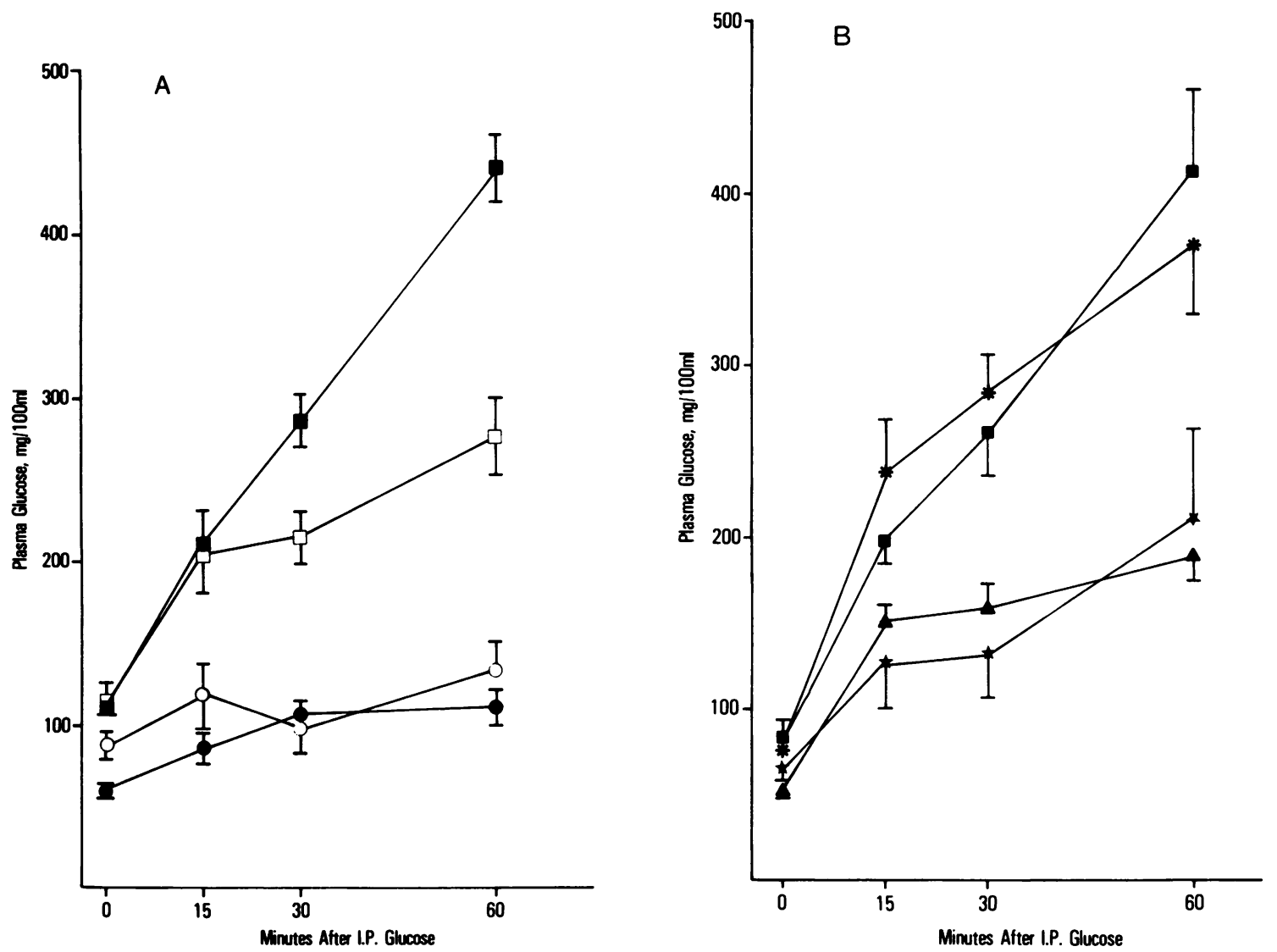

FIGURE 2 Effect of SOD treatment on streptozotocin-induced diabetes as assessed by glucose tolerance tests. Male Wistar rats, $175-225 \mathrm{~g}$, were injected i.v. with agents dissolved in $0.1 \mathrm{M}$ sodium acetate/acetic acid buffer, $\mathrm{pH} 5.2$. GTT were performed $5 \mathrm{~d}$ later after an 18 -h fast by i.p. injection of $1 \mathrm{~g} / \mathrm{kg}$ glucose. In A, streptozotocin was incubated with or without SOD at $37^{\circ} \mathrm{C}$ for $15 \mathrm{~min}$ before injection. Rats were treated with: diluent $(--\bullet), n=9$; SOD, $105 \mathrm{U} / \mathrm{g}(\mathrm{O}-\mathrm{O}), n=5 ;$ streptozotocin, $50 \mathrm{mg} / \mathrm{kg} \mathrm{( \square - \square ),} n=10$; and SOD + streptozotocin $(\square-\square), n=8$. In B, streptozotocin and SOD were dissolved immediately before injection, and administered sequentially. Rats were injected $10 \mathrm{~s}$ before streptozotocin with CNSOD, $35 \mu \mathrm{g} / \mathrm{g}\left({ }^{*}{ }^{*}\right), n=10$; or with SOD, $105 \mathrm{U} / \mathrm{g}=35 \mu \mathrm{g} / \mathrm{g}(\star-\star), n=$ 9. SOD was injected $50 \mathrm{~min}$ before streptozotocin $(\Delta-\Delta), n=7$. Streptozotocin alone $(50$ $\mathrm{mg} / \mathrm{kg}$ ) was injected in one series $(\square-\square), n=14$. Comparing the sum of all glucose values (0-60 min) for each animal (ANOVA) streptozotocin-injected rats were significantly protected against diabetes when injected with SOD either simultaneously with streptozotocin $(P<0.019)$ or $10 \mathrm{~s}(P<0.0007)$ or $50 \mathrm{~min}$ before streptozotocin $(P<0.0015)$. When each time point in the glucose tolerance tests was analyzed separately, no significant differences in fasting plasma glucose values were observed between rats injected with streptozotocin alone vs. any of the groups treated with streptozotocin and SOD. Each of the SOD treatment regimens resulted in significantly lower mean plasma glucose values 30 and $60 \mathrm{~min}$ after the glucose load as compared with controls treated with streptozotocin alone $(P<0.02-P<0.0001)$.

cemia was probably between 250 and $500 \mathrm{mg} / 100 \mathrm{ml}$ in the fed state. Decreases in glycemia of this magnitude after similar periods of food withdrawal have been documented in rats with moderate (nonketotic) diabetes $(20,21)$.

Mice. Male CD-l mice (Charles River Breeding Laboratories, Inc.), 30-35 g, were fasted overnight. Bovine erythrocyte SOD $(1,000 \mathrm{U} / \mathrm{g}$ body wt in $0.9 \mathrm{~g} / \mathrm{ml}$ sodium chloride, $200 \mathrm{mg} / \mathrm{ml}$ ) was injected into the tail vein or i.p. either immediately or $15 \mathrm{~min}$ before i.p. streptozotocin injection
(140 mg/ $\mathrm{kg}, 20 \mathrm{mg} / \mathrm{ml}$ in $100 \mathrm{mM}$ sodium acetate/acetic acid buffer, pH 5.2). Mice were tested for glycosuria and glycemia $5 \mathrm{~d}$ after streptozotocin.

\section{Statistical analysis}

Nonparametric analysis was performed on GTT results, defining diabetes as any plasma glucose exceeding $250 \mathrm{mg} /$ 
$100 \mathrm{ml}$ during GTT; Fisher's exact test was used (22). Parametric analysis of GTT results was performed using the sum of all glucose values (0-60 min) for a given animal; one way analysis of variance (ANOVA) was used (23). The significance of difference between multiple groups of islets with regard to insulin secretion, SOD enzyme specific activity, and radioimmunoassayable SOD content were also analyzed by ANOVA. Student's $t$ test was used where appropriate.

\section{RESULTS}

Effect of alloxan on enzymatic vs. radioimmunoassayable activity of purified canine erythrocyte $S O D$. The enzymatic activity and immunoreactivity of purified erythrocyte SOD were parallel upon serial dilution. Alloxan (1 fM-1 M) had no effect on the radioimmunoassay of SOD and thus interference by the presence of free alloxan with specific and/or nonspecific binding of immune complexes was eliminated; nonspecific binding was $97 \pm 3 \%$ of control and total binding was $95 \pm 0.8 \%$ of control $(n=16)$. When SOD was incubated with $40 \mathrm{mM}$ alloxan, enzymatic activity per milligram protein was inhibited $50 \%$ (3), resulting in a decreased ratio of enzymatic activity vs. radioimmunoassayable activity at all SOD dilutions tested. The mean specific activity of canine erythrocyte SOD was $2,866 \pm 551 \mathrm{U} / \mathrm{mg}$ for the native enzyme, and $1,288 \pm 181$ $\mathrm{U} / \mathrm{mg}$ for alloxan treated SOD, $(n=3, P<0.025)$.

Alloxan-induced inhibition of superoxide dismutase from intact islets and protection by D-glucose. Incubation of intact canine islets with alloxan in the presence of $4 \mathrm{mM}$ D-glucose resulted in inhibition of insulin release upon subsequent challenge with $28 \mathrm{mM}$ D-glucose, as described (6). The specific activity of SOD in the extracts of islets so treated was decreased by $40-60 \%(P<0.001)$. Increasing glucose to $28 \mathrm{mM}$ during incubation with alloxan prevented the alloxaninduced inhibition of insulin release as well as the decline in specific activity of SOD (Table I). Immunoreactive SOD content (nanograms per islet) was not affected by alloxan; neither the biological activity nor the immunoreactivity of SOD were altered by varying the glucose concentration in the medium.

SOD protection against streptozotocin toxicity in isolated canine islets. Incubation of isolated islets with streptozotocin resulted in inhibition of insulin release in response to a glucose stimulus (9). Islets that were exposed to SOD $(1.5 \mathrm{mg} / \mathrm{ml})$ for $10 \mathrm{~min}$ before addition of streptozotocin responded to glucose challenge as well as control islets not exposed to streptozotocin $(P<0.001$, Table II). CNSOD did not protect the islets against streptozotocin.

In vivo protection against streptozotocin by superoxide dismutases. All rats injected with streptozotocin alone developed diabetes as defined by $4^{+}$glycosuria and plasma glucose exceeding $250 \mathrm{mg} / 100 \mathrm{ml}$ 30-60 min after injection of glucose (Table III; Fig. 2 ). Rats treated with vehicle or SOD alone had plasma glucose $<250 \mathrm{mg} / 100 \mathrm{ml}$ during GTT. Intravenous injection of SOD $50 \mathrm{~min}$ before streptozotocin protected against the diabetogenic effect. Injection of

TABLE I

Alloxan-induced Inhibition of Superoxide Dismutase from Intact Islets and Protection by Glucose

\begin{tabular}{|c|c|c|c|c|c|c|c|}
\hline Group & $\begin{array}{l}\text { Pretreatment, } \\
\text { glucose }\end{array}$ & Alloxan & $\begin{array}{c}\text { Glucose } \\
\text { challenge }\end{array}$ & Insulin response & $\begin{array}{c}\text { SOD } \\
\text { sp. act. }\end{array}$ & $\begin{array}{l}\text { Normalized } \\
\text { sp. act. }\end{array}$ & $\begin{array}{c}\text { Immunoreactive } \\
\text { SOD }\end{array}$ \\
\hline & $m M$ & & $m M$ & $n g / 100$ islets $/ h$ & $U / m g$ & $\%$ & $n g /$ islet \\
\hline 1 & 4 & - & 4 & $4.27 \pm 2.4$ & $2028 \pm 332$ & $95 \pm 15$ & $43 \pm 7$ \\
\hline 2. & 4 & - & 28 & $23.8 \pm 3.7$ & $2270 \pm 532$ & $98 \pm 16$ & $52 \pm 6$ \\
\hline 3 & 28 & - & 4 & $5.5 \pm 2.1$ & $2347 \pm 332$ & $104 \pm 9$ & $46 \pm 3$ \\
\hline 4 & 28 & - & 28 & $28.7 \pm 9.1$ & $2074 \pm 301$ & $101 \pm 17$ & $63 \pm 8$ \\
\hline 5 & 4 & + & 4 & $3.6 \pm 1.5$ & $788 \pm 186$ & $37 \pm 3$ & $60 \pm 5$ \\
\hline 6 & 4 & + & 28 & $2.8 \pm 1.5$ & $1367 \pm 251$ & $59 \pm 7$ & $52 \pm 8$ \\
\hline 7 & 28 & + & 4 & $5.5 \pm 2.2$ & $2209 \pm 521$ & $103 \pm 21$ & $53 \pm 8$ \\
\hline 8 & 28 & + & 28 & $30.0 \pm 4.9$ & $2539 \pm 543$ & $115 \pm 18$ & $42 \pm 4$ \\
\hline
\end{tabular}

Islets (100/dish) were preincubated $10 \mathrm{~min}$ with glucose; alloxan was then added to some dishes for an additional 10 min. Following washing the islets were incubated for $1 \mathrm{~h}$ with 4 or $28 \mathrm{mM}$ glucose. Insulin released into the medium was measured, as well as the biological and immunoreactive SOD content of the islets. SOD specific activity = enzyme activity, U/radioimmunoassayable SOD, mg. Insulin secretion and SOD determinations are expressed as mean $\pm \mathrm{SEM} ; n=6-7$ observations in three separate experiments.

- Since there was some variability in SOD specific activity between experiments, normalized specific activities were calculated; $100 \%$ is defined as the mean SOD specific activity of all islets in a given experiment which were not exposed to alloxan. ANOVA of SOD sp act indicates that there is no difference between groups 5 and 6; or between the remaining groups. Group 5 is different from all other groups except $6(P<0.005)$. When groups 5 and 6 are treated as one population and compared to all observations in groups $1-4$ or in $7-8$ the mean of group $\Sigma 5-6$ is different from that of $\Sigma 1-4$, or $\Sigma 7-8, P<0.001$ Student's $t$ test. 
SOD immediately (10 s) before streptozotocin resulted in a similar level of protection; the glucose tolerance of these rats was significantly improved $(P<0.0007)$ over that of rats receiving streptozotocin alone but was significantly impaired as compared with controls receiving no streptozotocin $(P<0.01)$. While i.v. injection of SOD $50 \mathrm{~min}$ before streptozotocin appeared to be slightly more effective than the rapid sequential administration, neither parametric nor nonparametric analysis demonstrated a significant difference between these two groups. SOD injected 12 or $24 \mathrm{~h}$ before streptozotocin failed to protect against diabetes. Intravenous injection of one half the standard dose of SOD $10 \mathrm{~s}$ before streptozotocin was also ineffective.

Cyanide-inactivated SOD injected immediately before streptozotocin had no protective effect. Preincubation of streptozotocin with SOD prior to i.v. injection offered minimal protection and was less effective than SOD injection $10 \mathrm{~s}(P<0.02)$ or $50 \mathrm{~min}(P<0.03)$ before streptozotocin. Incubation of streptozotocin alone in vehicle for $15 \mathrm{~min}$ at $37^{\circ} \mathrm{C}$ did not decrease its diabetogenic effect in these experiments.

PEG-SOD was ineffective in protecting against streptozotocin diabetes when injected $50 \mathrm{~min}, 6 \mathrm{~h}$, or $12 \mathrm{~h}$ prior to streptozotocin. GTT were not performed on rats receiving PEG-SOD because all developed overt diabetes as defined by random nonfasting plasma glucose concentration of $400 \mathrm{mg} / 100 \mathrm{ml}$ or greater and $4^{+}$glycosuria.

GTT correlated with glycosuria as assessed by TesTape. Rats that were protected by SOD showed 0

TABLE II

Superoxide Dismutase Protection against Streptozotocin Toxicity in Isolated Canine Islets

\begin{tabular}{lccr}
\hline Pretreatment & Streptozotocin & $\begin{array}{c}\text { Glucose } \\
\text { stimulus }\end{array}$ & Insulin release \\
\hline & $0.1 \mathrm{mg} / \mathrm{ml}$ & $m M$ & $n g / 100$ islet $/ \mathrm{h}$ \\
None & - & 4 & $6.7 \pm 1.6(6)$ \\
None & - & 28 & $19.8 \pm 1.0(9)$ \\
None & + & 4 & $6.6 \pm 2.1(6)$ \\
None & + & 28 & $4.7 \pm 0.6(9)$ \\
SOD & + & 4 & $6.6 \pm 2.4(6)$ \\
SOD & + & 28 & $19.5 \pm 1.2(9)$ \\
SOD & - & 28 & $21.3 \pm 7.5(3)$ \\
CNSOD & - & 28 & $21.0 \pm 7.3(3)$ \\
CNSOD & + & 28 & $5.1 \pm 0.9(3)$ \\
\hline
\end{tabular}

100 islets/dish were preincubated with $4 \mathrm{mM}$ glucose for $10 \mathrm{~min}$ with or without SOD $(1.5 \mathrm{mg} / \mathrm{ml})$ or cyanide-inactivated SOD $(1.5$ $\mathrm{mg} / \mathrm{ml}$ ). Streptozotocin was added to some dishes for an additional $10 \mathrm{~min}$; then the islets were washed and incubated for $1 \mathrm{~h}$ with 4 or $28 \mathrm{mM}$ glucose and insulin released into the medium measured. Values are means \pm SEM; the number of observations is shown in parentheses.
TABLE III

In Vivo Protection of Rats against Streptozotocin by Superoxide Dismutases

\begin{tabular}{|c|c|c|c|}
\hline Injections & & $\begin{array}{l}\text { Time from SOD } \\
\text { to } S z \text { injection }\end{array}$ & Diabetic animals \\
\hline & & & $\%$ \\
\hline Enzyme & $\mathrm{Sz}$ & & \\
\hline SOD, $105 \mathrm{U} / \mathrm{g}$ & - & & $0, n=4$ \\
\hline - & + & & $100, n=14$ \\
\hline - & $+^{\circ}$ & & $100, n=10$ \\
\hline SOD, $105 \mathrm{U} / \mathrm{g}$ & $+^{\circ}$ & $0 \mathrm{~min}$ & $75, n=8$ \\
\hline $\mathrm{SOD}, 52 \mathrm{U} / \mathrm{g}$ & + & $10 \mathrm{~s}$ & $75, n=4$ \\
\hline SOD, $105 \mathrm{U} / \mathrm{g}$ & + & $10 s$ & $33, n=9$ \\
\hline SOD, $105 \mathrm{U} / \mathrm{g}$ & + & $50 \mathrm{~min}$ & $0, n=7$ \\
\hline SOD, $105 \mathrm{U} / \mathrm{g}$ & + & $12 \mathrm{~h}$ & $100 \ddagger, n=6$ \\
\hline SOD, $105 \mathrm{U} / \mathrm{g}$ & + & $24 \mathrm{~h}$ & $100 \ddagger, n=6$ \\
\hline CNSOD, $35 \mu \mathrm{g} / \mathrm{g}$ & + & $10 \mathrm{~s}$ & $100, n=10$ \\
\hline PEG-SOD, $105 \mathrm{U} / \mathrm{g}$ & + & $50 \mathrm{~min}$ & $100 t, n=4$ \\
\hline PEG-SOD, $105 \mathrm{U} / \mathrm{g}$ & + & $6 \mathrm{~h}$ & $100 \ddagger, n=2$ \\
\hline PEG-SOD, $105 \mathrm{U} / \mathrm{g}$ & + & $12 \mathrm{~h}$ & $100 \ddagger, n=2$ \\
\hline
\end{tabular}

SOD, CNSOD, or PEG-SOD were administered i.v. at the times indicated before i.v. injection of streptozotocin $(\mathrm{Sz}, 50 \mathrm{mg} / \mathrm{kg})$. Rats not receiving one of the agents were injected i.v. with diluent. Streptozotocin was dissolved immediately before injection except as designated by ${ }^{\circ}$ where streptozotocin or a streptozotocin/SOD mixture was incubated $15 \mathrm{~min}$ at $37^{\circ} \mathrm{C}$ in $100 \mathrm{mM}$ sodium acetate/ acetic acid buffer, pH 5.2, before injection. In this analysis except as noted by $\downarrow$, rats were classified as diabetic if their plasma glucose exceeded $250 \mathrm{mg} / 100 \mathrm{ml} 30$ or $60 \mathrm{~min}$ after i.p. injection of $1 \mathrm{~g} /$ $\mathrm{kg}$ glucose following an 18 -h fast on day 5 after streptozotocin injection.

† GTT was not performed. Animals had nonfasting plasma glucose values exceeding $400 \mathrm{mg} / 100 \mathrm{ml}$ and $4^{+}$glucosuria.

$1^{+}$glycosuria while unprotected streptozotocin injected rats showed $3-4^{+}$glycosuria.

Neither intravenous nor intraperitoneal SOD altered the course of acute streptozotocin diabetes in CD-1 mice $(n=8)$. All animals injected with streptozotocin had $3-4^{+}$glycosuria whether or not they received SOD.

\section{DISCUSSION}

We have previously shown that alloxan inhibits the enzymatic activity of purified erythrocyte SOD and that of SOD extracted from rat and canine islets (3). The present results demonstrate that when alloxan damages intact islets, it concomitantly inhibits SOD activity. The decrease in the biological activity of SOD after incubation of intact islets with alloxan was of the same magnitude as the maximal inhibition observed when purified erythrocyte SOD or SOD extracted from islets was incubated with increasing concentrations of the drug (3). Alloxan did not diminish immunoreactive 
SOD, suggesting that normal antigenicity was retained. Because the enzyme is localized to the cytosol, alloxan or a metabolite or alloxan-generated oxygen species must have entered the cell. Hydrogen peroxide, a known inactivator of SOD (24), is known to be produced in the metabolism of alloxan (1) and may mediate this effect. It is noteworthy that inhibition of SOD activity, which can be achieved with $\mathrm{H}_{2} \mathrm{O}_{2}$ (22) or with alloxan, streptozotocin, or Vacor (3), is $\sim 50 \%$.

When the islets were protected from alloxan toxicity by high glucose in the medium, SOD specific activity was unaffected by alloxan. The mechanism of glucose protection is controversial. There is evidence suggesting that glucose may compete with alloxan for a membrane-associated receptor (6), an intracellular receptor (25), or that glucose may provide protective reducing equivalents inside the cell (26). We have previously shown that in a cell-free system glucose does not protect SOD from alloxan inhibition (3). Thus, the protection of SOD by glucose in intact islets would not represent a direct effect of glucose upon SOD-alloxan interaction. Our data cannot discriminate between the above hypotheses concerning the effect of glucose; however, the fact that SOD specific activity correlated with maintenance of $\beta$-cell function supports the hypothesis that inhibition of islet SOD is one of the deleterious effects whereby alloxan damages $\beta$-cells. Because the kinetics of SOD inhibition have not been characterized, it is possible that the measured $50 \%$ inhibition of enzyme activity represents an even greater loss of biological protection in the cell if, e.g., alloxan exposure decreases the affinity of the enzyme for its substrate.

In vitro, Fischer and Hamburger (27) have shown that SOD can protect beta cells against alloxan, and suggested a relationship between oxygen radical generation and alloxan toxicity. The fact that SOD completely protected islets in vitro against streptozotocin toxicity suggests that this agent may also generate oxygen radicals. In our in vitro experiments (Table II) SOD was removed before testing the islets' capacity to release insulin in response to glucose; thus the protective effect was not an artifact of increased protein concentration in the medium inhibiting insulin degradation. The failure of CNSOD to protect against streptozotocin is evidence of the specificity of the protective effect of SOD enzyme activity. Gold et al. (9) recently reported that $S O D$ at one-tenth the dose used in the experiments reported here failed to protect rat islets in vitro against streptozotocin. However, these investigators have since observed partial protection in their system. ${ }^{2}$ Thus, the discrepancy between these

${ }^{2}$ Grodsky, G. M. Personal communication. results may represent species, i.e., dog vs. rat, or SOD dose differences.

Problems associated with the canine islet preparation have been discussed by Scharp et al. (12). Misidentification of pancreatic acinar fragments of size and shape similar to islets can lead to significant acinar contamination and overestimation of islet number. The basal and stimulated insulin secretion rates per islet reported here are lower than those observed by Downing et al. (13) in canine islets; however the ratios of basal/stimulated secretion ( 0.33 ) were identical in the two studies. The criterion of insulin/amylase ratio has been proposed (11) for the evaluation of the purity of islet preparations; reported ratios of 70-100 $\mu \mathrm{g}$ insulin per milligram amylase (11) are similar to our determination of $67 \mu \mathrm{g}$ insulin per milligram amylase in a representative preparation.

There has been recent controversy concerning the ability of SOD to protect against streptozotocin-induced diabetes. Our in vivo experiments in rats confirm the observation of Robbins et al. (8). The differences between the experiments of Robbins et al. and Gold et al. (9) are best explained by species differences because in our hands large doses of SOD ( $\times 10$ greater per gram body weight than the protective dose in rats) failed to protect against streptozotocin-induced diabetes in the CD-1 mouse.

Our experiments show that the protective effect of SOD is linked to enzyme activity; cyanide-inactivated enzyme was ineffective. Protection is unlikely due to interaction or binding of streptozotocin and SOD in the circulation because preincubation of the enzyme with the drug offered much less protection than sequential injection of SOD followed by streptozotocin. Note that preincubation of streptozotocin alone at $\mathrm{pH}$ 5.2 did not result in significant loss of diabetogenic activity in these experiments. Rapid sequential injection of SOD followed by streptozotocin significantly improved glucose tolerance as compared with streptozotocin alone: $66 \%$ of rats so treated were partially protected from diabetes.

Injection of SOD $50 \mathrm{~min}$ before streptozotocin was equal or better in protective efficacy to rapid sequential injection. Because the plasma $t_{1 / 2}$ of the enzyme is $6 \mathrm{~min}(28)$, the amount of SOD remaining in the circulation after $50 \mathrm{~min}$ should be negligible. Thus, the persistence of the protective effect suggests that the enzyme induces prolonged metabolic changes in the $\beta$-cell or, more likely, that the enzyme enters cells and intracellular $t_{1 / 2}$ is longer than that in plasma. Petkau et al. (29) and Kelly et al. (30) have reported uptake of SOD into blood cells, marrow cells, hepatocytes, and kidney cells as demonstrated by the use of ${ }^{125}$ I-SOD or radioimmunoassay of species specific 
SOD. Although we have no information concerning the $t_{1 / 2}$ of intracellular SOD, no protection was observed when SOD was injected $12 \mathrm{~h}$ or longer before streptozotocin.

The half life of PEG-SOD in plasma has been reported to be $35 \mathrm{~h}$ (28). We hoped that treatment of rats with PEG-SOD might offer continuous protection with once or twice daily injections. However, in our hands PEG-SOD was completely ineffective in protecting at $50 \mathrm{~min}, 6 \mathrm{~h}$, or $12 \mathrm{~h}$ before streptozotocin. Since unit-equivalent doses of SOD activity were delivered, it appears likely that our PEG-SOD did not gain access to the intracellular space.

While this manuscript was in preparation, Grankvist et al. (31) reported attenuation of diabetes in mice treated with PEG-SOD $12 \mathrm{~h}$ before the i.v. injection of alloxan. There are several differences between Grankvist's studies and ours (e.g., rat vs. mouse, streptozotocin vs. alloxan, relative dose of diabetogenic agent). A most likely discrepancy may be in the preparation of the PEG derivative, as Grankvist observed a complex disappearance curve of PEG-SOD from serum, with an apparent $t_{1 / 2}$ of $6 h$, as contrasted with $35 \mathrm{~h}$ reported by McCord and Wong (28). The derivatives may be heterogeneous and the molecular size or structure may determine their efficacy. The success of Grankvist's experiments suggest that long acting derivatives of SOD may indeed prove useful in the prophylaxis of experimental chemically induced diabetes and may be worthy of testing in other animal models of diabetes.

SOD may play a role in the pathogenesis of insulindependent diabetes. Known etiological factors include viral, autoimmune, and/or toxic insults (32). Recent work by Pottathil et al. (33) indicates that intracellular SOD is linked to interferon-mediated antiviral competence. Furthermore, $T$ cell-generated lymphokines may induce oxygen radical production in target cells (34). SOD has been suggested to be required for activity of suppressor T lymphocytes (35). Thus, the effectiveness of exogenously administered SOD in protecting $\beta$-cells against insult in vitro and in vivo may reflect exquisite vulnerability of these cells to oxygen radical damage and/or a critical dependence on oxygen radical scavengers.

\section{ACKNOWLEDGMENTS}

We thank Dr. Boyd Loadholt, Department of Biometry, Medical University of South Carolina, for his valuable assistance with statistical analysis, and Mrs. Barbara Whitlock for secretarial help in the preparation of this manuscript.

This research was supported in part by a grant from the American Diabetes Association and by grant AM-02001 from the National Institute of Arthritis, Diabetes, Digestive and Kidney Diseases.

\section{REFERENCES}

1. Cohen, G., and R. E. Heikkila. 1974. The generation of hydrogen peroxide, superoxide radical, and hydroxyl radical by 6 -hydroxy-dopamine, dialuric acid, and related cytotoxic agents. J. Biol. Chem. 249: 2447-2452.

2. Fridovich, I. 1975. Superoxide dismutases. Annu. Rev. Biochem. 44: 147-159.

3. Crouch, R. K., S. E. Gandy, G. Kimsey, R. A. Galbraith, G. M. P. Galbraith, and M. G. Buse. 1981. The inhibition of islet superoxide dismutase by diabetogenic drugs. Diabetes. 30: 235-241.

4. Gandy, S. E., R. A. Galbraith, R. K. Crouch, M. G. Buse, and G. M. P. Galbraith. 1981. Superoxide dismutase in human islets of Langerhans. N. Engl. J. Med. 304: 15471548.

5. Crouch, R., G. Kimsey, D. G. Priest, A. Sarda, and M. G. Buse. 1978. Effect of streptozotocin on erythrocyte and retinal superoxide dismutase. Diabetologia. 15: 5357.

6. Weaver, D. C., M. L. McDaniel, S. P. Naber, C. D. Barry, and $P$. E. Lacy. 1978. Alloxan stimulation and inhibition of insulin release from isolated rat islets of Langerhans. Diabetes. 27: 1205-1214.

7. Grankvist, K., S. Marklund, J. Sehlin, and I-B. Taljedal. 1979. Superoxide dismutase, catalase and scavengers of hydroxyl radical protect against the toxic action of alloxan on pancreatic islet cells in vitro. Biochem. J. 182: 17-25.

8. Robbins, M. J., R. A. Sharp, A. E. Slonim, and I. M. Burr. 1980. Protection against streptozotocin-induced diabetes by superoxide dismutase. Diabetologia. 18: 55-58.

9. Gold, G., M. Manning, A. Heldt, R. Nowlain, J. R. Pettit, and G. M. Grodsky. 1981. Diabetes induced with multiple subdiabetogenic doses of streptozotocin: lack of protection by exogenous superoxide dismutase. Diabetes. 30: 634-638.

10. Abuchowski, A., T. van Es, N. C. Palczuk, and F. F. Davis. 1977. Alteration of immunological properties of bovine serum albumin by attachment of polyethylene glycol. J. Biol. Chem. 252: 3578-3581.

11. Matas, A. J., D. E. R. Sutherland, M. W. Steffes, and J. S. Najarian. 1976. Short-term culture of adult pancreatic fragments for purification and transplantation of islets of Langerhans. Surgery (St. Louis). 80: 183-191.

12. Scharp, D. W., R. Downing, R. C. Merrell, and M. Greider. 1980. Isolating the elusive islet. Diabetes. 29(Suppl. 1): 19-309.

13. Downing, R., D. W. Scharp, M. Greider, and W. F. Ballinger. 1979. Mass isolation of islets of Langerhans from the dog pancreas. Diabetes. 28: 426.

14. Rabinovitch, A., L. Fuller, D. Mintz, W. Severyn, J. Noel, C. Flaa, G. Kyriakides, and J. Miller. 1981. Responses of canine lymphocytes to allogeneic and autologous islets of Langerhans in mixed cell cultures. J. Clin. Invest. 67: 1507-1516.

15. Marklund, S., and G. Marklund. 1974. Involvement of the superoxide anion in the autoxidation of pyrogallol and a convenient assay for superoxide dismutase. Eur. J. Biochem. 47: 469-474.

16. Marchalonis, J. J. 1969. An enzymic method for the trace iodination of immunoglobulins and other proteins. Biochem. J. 113: 299-305.

17. Crouch, R., D. G. Priest, and E. J. Duke. 1978. Superoxide dismutase activities of bovine ocular tissues. Exp. Eye Res. 27: 503-509. 
18. Kansal, P. C., and M. G. Buse. 1967. The effect of adrenergic blocking agents on plasma insulin and blood glucose during urethan or epinephrine induced hyperglycemia. Metab. Clin. Exp. 16: 548-556.

19. Morgan, C. R., and A. Lazarow. 1963. Immunoassay of insulin: two antibody system. Diabetes. 12: 115-126.

20. Bauer, B. A., and E. S. Younathan. 1980. Gas chromatographic determination of the anomers of blood glucose in normal and diabetic rats. Biochem. Med. 24: 293299.

21. Kazumi, T., M. Utsumi, G. Yoshiro, K. Ishihara, Y. Hirose, $H$. Makimura, and S. Baba. 1980. Somatostatin concentration responds to arginine in portal plasma. Effects of fasting, streptozotocin diabetes and insulin administration in diabetic rats. Diabetes. 29: 71-73.

22. Colquhon, D. 1971. Lectures on Biostatistics. Clarenden Press, Oxford, England. 116-136.

23. Colquhon, D. 1971. Lectures on Biostatistics. Clarenden Press, Oxford, England. 171-216.

24. Hodgson, E. K., and I. Fridovich. 1975. The interaction of bovine erythrocyte superoxide dismutase with hydrogen peroxide. Biochemistry. 14: 5294-5299.

25. Weaver, D. C., M. L. McDaniel, and P. E. Lacy. 1978. Alloxan uptake by isolated rat islets of Langerhans. Endocrinology. 102: 1847-1855.

26. Boquist, L. 1980. A new hypothesis for alloxan diabetes. Acta Pathol. Microbiol. Scand. Sect. A Pathol. 88: 201209.

27. Fischer, L. J., and S. A. Hamburger. 1980. Inhibition of alloxan action in isolated pancreatic islets by superoxide dismutase, catalase and a metal chelator. Diabetes. 29: 213-216.
28. McCord, J. M., and K. Wong. 1979. Phagocyte-produced free radicals: roles in cytotoxicity and inflammation. In Oxygen Free Radicals and Tissue Damage. Ciba Foundation Symposium 65. Elsevier-North Holland, Amsterdam. 343-360.

29. Petkau, A., K. Kelly, W. S. Chelak, S. D. Pleskach, C. Barefoot, and B. E. Meeker. 1975. Radioprotection of bone marrow cells by superoxide dismutase. Biochem. Biophys. Res. Commun. 67: 1167-1174.

30. Kelly, K., C. Barefoot, A. Sehon, and A. Petkau. 1978. Bovine superoxide dismutase: a radioimmunoassay. Arch. Biochem. Biophys. 190: 531-538.

31. Grankvist, K., S. Marklund, and I-B. Taljedal. 1981. Superoxide dismutase is a prophylactic against alloxan diabetes. Nature (Lond.). 294: 158-160.

32. Cahill, G. F., and H. O. McDevitt. 1981. Insulin-dependent diabetes mellitus: the initial lesion. N. Engl. J. Med. 304: 1454-1465.

33. Pottathil, R., K. A. Chandrabose, P. Cuatrecasas, and D. J. Lang. 1981. Establishment of the interferon-mediated antiviral state: possible role of superoxide dismutase. Proc. Natl. Acad. Sci. USA. 78: 3343-3347.

34. Keisari, Y., and E. Pick. 1980. Lymphokine mimicry by phorbol myristate acetate (PMA) and the ionophore A23187-a new hypothesis for explaining the action mechanism of migration inhibitory factor (MIF). In Biochemical Characterization of Lymphokines. A. L. deWeck, F. Kristensen, and M. Landy, editors. Academic Press, Inc., New York. 113-121.

35. Harman, D. 1981. The aging process. Proc. Natl. Acad. Sci. USA. 78: 7124-7128. 